\title{
UPAYA MENCEGAH ANAK BEKERJA DI JALANAN: APLIKASI KUALITATIF TEORI MOTIVASI PROTEKSI
}

\author{
William Cahyawan ${ }^{1} \&$ Wahyu Cahyo Nugroho ${ }^{2}$ \\ ${ }^{1}$ Division for Applied Social Psychology Research, Daya Makara, Universitas Indonesia, Jl. Ir. H. Juanda No. 1, \\ Pasar Baru, Jakarta 10110, Indonesia \\ ${ }^{2}$ Fakultas Psikologi, Universitas Katolik Indonesia Atma Jaya, Jl. Jenderal Sudirman 51, Jakarta 12930, \\ Indonesia
}

Korespondensi:

Ie-mail: williamcahyawan@gmail.com

\begin{abstract}
This study seeks to explore the mothers of street children's appraisal by using Protection Motivation Theory. Only a few studies have been conducted regarding the parents of street children, although the phenomenon of street children is also caused by parental factors. This study aims to discover the mothers' appraisal on the threats faced by their children and their responses to prevent their children from working in the street. Three mothers of street children in East Jakarta participated in this study. Data are presented descriptively along with quoted verbatim from the interview. The participants assessed several possible threats faced by their children, while acknowledging the result of financial gains they may get. However, there are some who were not sure in responding that way and opted to respond in another manner to reduce the likelihood of the occurrence of harm suffered by their children. Other related findings are discussed as well.
\end{abstract}

Article history:

Received 2 February 2018

Received in revised form 3 April 2018

Accepted 9 July 2018

Available online 21 September 2018

\section{Keywords:}

mothers of street children;

protection motivation theory;

street children

\begin{abstract}
Abstrak - Penelitian ini berusaha mengeksplorasi penilaian ibu dari anak jalanan dengan menggunakan Teori Motivasi Proteksi. Studi terhadap orang tua anak jalanan belum banyak ditemukan, padahal keberadaan anak di jalanan salah satunya dikarenakan faktor orang tua. Penelitian berupaya mencari tahu penilaian ibu tentang ancaman yang dihadapi anak dan penilaian terhadap respons untuk mencegah anak bekerja di jalanan. Partisipan penelitian ialah tiga orang ibu dari anak jalanan di Jakarta Timur. Data disajikan secara deskriptif disertai dengan kutipan hasil wawancara. Partisipan menilai terdapat beberapa bahaya yang mungkin diderita anak, walaupun juga terdapat keuntungan finansial yang didapatkan. Ada beberapa partisipan yang merasa tidak yakin mampu melakukan respons tersebut dan memilih melakukan respons lain untuk mengurangi kemungkinan anak terkena bahaya. Hasil penelitian lain yang berkaitan juga turut didiskusikan.
\end{abstract}

Kata kunci: anak jalanan; ibu anak jalanan; teori motivasi proteksi 


\section{PENDAHULUAN}

Penyandang Masalah Kesejahteraan Sosial (PMKS) adalah seseorang, keluarga, atau kelompok masyarakat yang karena suatu hambatan, kesulitan, atau gangguan tidak dapat melaksanakan fungsi sosialnya yang berakibat pada tidak terpenuhinya kebutuhan hidup yang memadai dan wajar secara jasmani maupun sosial (Nuryetty dkk., 2012). Salah satu jenis PMKS di Indonesia adalah anak jalanan (Dinas Sosial Daerah Istimewa Yogyakarta, 2018). Berdasarkan definisinya, anak jalanan adalah anak yang melewatkan atau memanfaatkan sebagian besar waktunya untuk melakukan kegiatan sehari-hari di jalanan, termasuk di lingkungan pasar, pertokoan, dan pusat-pusat keramaian lainnya (Kementerian Sosial Republik Indonesia, 2017).

Permasalahan anak jalanan merupakan masalah yang perlu segera diatasi dan dicari solusinya karena kondisinya yang memprihatinkan. Kehidupan anak di jalanan membuat mereka rentan menghadapi berbagai macam bahaya antara lain, rawan tertabrak kendaraan dan mengalami kecelakaan, terkena penyakit akibat polusi udara dan lingkungan yang buruk, penyalahgunaan zat berbahaya, dan risiko perilaku seksual yang tinggi sejak dini (Handy \& Soedjatmiko, 2004; Suyanto, 2010), berbagai macam bentuk kekerasan seperti kekerasan psikis, fisik, dan finansial (UNICEF, 2007; Suyanto, 2010; Persada, 2012), serta kekerasan seksual (Sedayu, 2010).

Bahaya yang dihadapi oleh anak karena bekerja di jalanan jelas bertentangan dengan isi Undang-Undang Republik Indonesia (UU RI) Nomor 35 tahun 2014 Pasal 1 tentang perlindungan anak yang menjelaskan bahwa anak harus dijamin dan dilindungi, serta memeroleh hak-haknya agar dapat hidup, tumbuh, berkembang, dan berpartisipasi secara optimal sesuai dengan harkat dan martabat kemanusiaan, serta mendapat perlindungan dan non-diskriminasi. Sesuai dengan isi Undang-Undang Republik Indonesia (UU RI) Nomor 35 tahun 2014 Pasal 26, orang tua seharusnya memiliki peran dan tanggung jawab untuk mengasuh, memelihara, mendidik, dan melindungi anak (Komisi Perlindungan Anak Indonesia, 2014). Orang tua sebagai lingkungan terdekat anak memiliki kewajiban untuk menanamkan hal baik dalam rangka mengembangan kepribadian, serta mengupayakan agar anak terhindar dari bahaya (Gunarsa \& Gunarsa, 2008). Orang tua harus membimbing dan mengutamakan kepentingan terbaik bagi anak, termasuk menjaga dan memelihara hak asasi anak (UNICEF, 1989). Jika dilihat dari perannya, orang tua seharusnya memainkan peranan penting bagi perilaku anak.

Peneliti menilai studi terhadap perspektif orang tua anak jalanan menjadi penting dalam upaya mengatasi permasalahan anak jalanan. Oleh karena itu, peneliti tertarik untuk melakukan studi sebagai upaya mencari tahu tentang penilaian orang tua untuk mencegah anaknya bekerja di 
jalanan. Fokus dari penelitian ditujukan pada para ibu anak jalanan yang dianggap lebih sering berinteraksi dengan anaknya sehari-hari. Teknik pengumpulan data dilakukan dengan wawancara dan panduannya mengacu pada konsep Protection Motivation Theory (PMT).

\section{Protection Motivation Theory (PMT)}

Protection motivation Theory (PMT) merupakan teori yang dikembangkan oleh Rogers pada tahun 1975 (Rogers, 1983; Sutton, 2001). Teori ini dibangun berdasarkan kerangka berpikir teori kognitif sosial (Marks, 2002) dan merupakan model dasar intervensi individu ataupun komunitas (Floyd, Dunn, \& Rogers, 2000). Penelitian mengenai PMT secara khusus memiliki dua tujuan utama. Pertama, PMT menggunakan model kognisi sosial untuk memprediksi perilaku protektif individu. Tujuan kedua, PMT dapat dimanipulasi menggunakan komunikasi persuasif yang menekankan kognisi guna mengevaluasi perilaku serta membentuk intensi individu untuk melakukan perilaku protektif (Rogers \& Dunn, 1997).

Sesuai dengan tujuan PMT, peneliti menilai bahwa teori ini dapat digunakan dalam upaya melihat, memprediksi perilaku ibu, mengevaluasi perilaku, serta membentuk intensi para ibu supaya dapat melindungi anaknya yang bekerja di jalanan. Kondisi ini penting karena orang tua memiliki kewajiban untuk mengasuh, menjaga, melindungi, dan memelihara anaknya. Tinjauan literatur dan penelitian tentang PMT mengindikasikan bahwa teori ini telah diaplikasikan pada berbagai macam topik, termasuk area-area di luar isu yang berhubungan dengan kesehatan. Selain mempromosikan kesehatan dan mencegah terjadinya penyakit, PMT telah digunakan untuk meneliti isu politik, masalah lingkungan, dan keinginan untuk melindungi orang lain (Rogers \& Dunn, dalam Floyd dkk., 2000). Studi-studi sebelumnya tentang PMT memperlihatkan bahwa teori ini telah diperluas untuk melihat respons individu bagi kepentingan orang lain, termasuk respons dari orang tua terhadap anaknya (Rogers \& Dunn, 1997).

Menurut Rogers (1983), PMT menjelaskan dampak dari fear appeals terhadap respons kognitif individu. Fear appeals didefinisikan sebagai informasi yang dikomunikasikan terkait ancaman bagi kesejahteraan individu (Rogers, dalam Milne, 2000). Proses kognitif menghasilkan dua penilaian terhadap ancaman, yaitu penilaian ancaman (threat appraisal) dan penilaian coping (coping appraisal). Kedua penilaian tersebut menghasilkan motivasi individu untuk menginisiasi, melanjutkan, atau justru menghalangi munculnya respons adaptif. Motivasi proteksi (protection motivation) mengacu pada motivasi individu untuk menghindari ancaman, atau biasa didefinisikan sebagai intensi individu untuk menyetujui respons adaptif yang digunakan sebagai upaya menghindari ancaman (Rogers, 1983). 
Penilaian ancaman menghasilkan motivasi individu untuk melakukan respons maladaptif. Menurut Rogers (1983), penilaian ancaman diinisasi oleh sumber informasi dari lingkungan (misalnya: observasi) dan intrapersonal (misalnya: pengalaman masa lalu). Komponen penilaian ancaman terdiri dari penilaian terhadap kemungkinan munculnya keparahan ancaman (perceived severity) dan seberapa besar kemungkinan terkena ancaman tersebut (perceived vulnerability). Meskipun ancaman umumnya mengacu pada potensi membahayakan tubuh, tetapi ancaman juga dapat melibatkan ancaman intrapersonal (seperti: self-esteem) dan ancaman interpersonal (seperti: hubungan keluarga dan pekerjaan) (Rogers, 1983). Norman, Boer, dan Seydel (2005) juga menjelaskan keparahan berkaitan dengan kerugian kondisi ekonomi atau bahkan membahayakan orang lain.

Satu aspek lain lagi dalam penilaian ancaman, yaitu rewards. Menurut Rogers (1983), ada sejumlah faktor rewards, baik secara intrinsik (misalnya: kesenangan) maupun ekstrinsik (misalnya: penerimaan sosial) yang meningkatkan kemungkinan individu melakukan respons maladaptif. Jika penilaian individu terhadap ancaman mengurangi dan menghalangi kemungkinan munculnya respons maladaptif, penilaian individu terhadap rewards akan membentuk dan meningkatkan respons maladaptif (Norman dkk., 2005).

Namun di sisi lain, penilaian coping merupakan proses untuk mengatasi dan mencegah terjadinya ancaman berbahaya. Proses terbentuknya penilaian coping melalui kemunculan respons efikasi (response efficacy) dan efikasi diri (self-efficacy) (Floyd dkk., 2000). Respons efikasi merupakan keyakinan bahwa coping response yang direkomendasikan efektif untuk mencegah munculnya ancaman (misalnya: berhenti merokok merupakan cara terbaik untuk menghindarkan ancaman yang diasosiasikan dengan merokok). Efikasi diri adalah keyakinan individu untuk dapat menerapkan coping response (misalnya: saya dapat berhenti merokok) (Rogers, 1983).

Ketika respons efikasi dan efikasi diri membantu terbentuknya kemungkinan respons adaptif, terdapat sejumlah halangan (response costs), misalnya ketidaknyamanan, beban, kesulitan, efek samping, serta segala "harga" yang harus "dibayar" untuk melakukan respons adaptif (Rogers, 1983). Respons adaptif adalah kemampuan individu untuk menyesuaikan diri terhadap suatu peristiwa, sehingga dapat mengurangi munculnya ancaman (Norman dkk., 2005). 


\section{METODE}

\section{Partisipan}

Subjek dalam penelitian ini adalah tiga orang ibu anak jalanan yang berasal dari Jakarta Timur. Wilayah ini dipilih karena berdasarkan data Badan Pusat Statistik Provinsi DKI Jakarta (2013), anak jalanan paling banyak tinggal di wilayah Jakarta Timur (58\%), diikuti dengan wilayah Jakarta Utara (25\%), Jakarta Selatan (9\%), Jakarta Barat (4\%), serta Jakarta Pusat (4\%). Dua partisipan (disebut sebagai subjek A dan B) tinggal di daerah Prumpung Sawah dan satu partisipan lainnya (subjek C) tinggal di daerah Kebon Singkong. Kedua daerah terletak di wilayah Jakarta Timur.

Jalan di daerah Prumpung Sawah tidak terlalu besar dan rumah dari kedua subjek berlokasi di sebuah gang sempit yang hanya dapat dilalui oleh motor. Pemukiman di daerah tersebut tidak terlalu besar, subjek A dan B tinggal dengan mengontrak. Rumah subjek A relatif lebih baik kondisinya karena terdapat kipas angin dan televisi kecil, serta berukuran 4 x 4 ubin. Sementara itu, rumah subjek B kondisinya lebih gelap, karena tidak terdapat penerangan dan perabotan yang memadai, serta ukurannya yang hanya 2 x 3 ubin. Bahkan, kamar mandi di rumah subjek B tidak memiliki sekat atau pembatas. Wilayah tersebut juga digunakan sebagai lokasi tempat pembuangan sampah dan berada di dekat sungai. Kondisi serupa juga terjadi di daerah Kebon Singkong yang dekat dengan sungai dan wilayah pemukimannya lebih besar dan padat. Rumah subjek $\mathrm{C}$ hanya terdiri dari alas tidur saja. Rumahnya tidak memiliki tempat memasak ataupun kamar mandi. Apabila ingin memasak atau ke toilet, maka subjek $\mathrm{C}$ akan pergi ke tempat mandi dan masak umum.

Pada profil keluarga, subjek A sudah bercerai dengan suaminya, sehingga ia seorang diri mengurusi anak-anaknya yang berjumlah 3 orang. Pekerjaan sehari-hari subjek A adalah bekerja sebagai penadah beras, pembantu rumah tangga, dan juga mengamen di jalanan bersama dengan kedua anaknya (perempuan) yang paling kecil. Anak perempuan tertua dari subjek A masih bersekolah dan mulai masuk jenjang SMP. Sejak kecil, anak tertua subjek A sudah bekerja di jalanan bersama dengan subjek A. Sekarang, anak tertua subjek A terbiasa seorang diri menjadi pemulung atau pengamen. Namun, aktivitas ini tidak dilakukan setiap hari.

Sementara itu, subjek B memiliki dua anak. Suami subjek B bekerja dengan mencari rongsokan bekas. Subjek B biasanya bekerja dengan membuka usaha makanan kecil-kecilan dan mengamen di jalanan bersama anaknya yang paling kecil (perempuan). Subjek B biasa mengamen apabila sedang tidak memiliki uang. Anak tertua (perempuan) subjek B juga ikut mengamen. Sejak 
berusia 2 tahun, anak tertua subjek B sudah diajak bekerja di jalanan oleh subjek B. Saat ini, anak tertua subjek B mengamen seorang diri atau bersama dengan nenek atau temannya. Anak tertua subjek B masih sekolah, namun sudah sering bolos atau tidak masuk. Subjek B mengatakan anaknya terancam putus sekolah apabila sering bolos.

Subjek terakhir, subjek C memiliki 5 anak. Suami subjek C bekerja sebagai tukang angkut sampah, serta pernah menjadi buruh bangunan dan bekerja serabutan. Subjek C bekerja sebagai pembantu rumah tangga. Anak subjek $\mathrm{C}$ yang bekerja di jalanan hanya 1 orang (laki-laki), karena dulunya diajak oleh teman-temannya dan ia sudah terbiasa menjadi pengamen jalanan. Ia bekerja di jalanan sejak kelas IV SD. Setelah bekerja di jalanan, anak subjek C sudah tidak lagi bersekolah.

Ketiga subjek lahir dan besar di Jakarta dan menempuh pendidikan di Jakarta. Usia subjek A adalah 35 tahun, subjek B berusia 29 tahun, dan subjek C berusia 37 tahun. Subjek A dan B pernah bersekolah sampai kelas VI Sekolah Dasar, tetapi tidak tamat. Sementara pendidikan terakhir subjek C adalah Sekolah Dasar (SD). Berikut adalah tabel data demografi subjek untuk memudahkan pemahaman pembaca.

Tabel 1.

Rangkuman Data Demografi Subjek

\begin{tabular}{|c|c|c|c|}
\hline Keterangan & Subjek 1 & Subjek 2 & Subjek 3 \\
\hline Nama (inisial) & $\mathrm{A}$ & $\mathrm{B}$ & $\mathrm{C}$ \\
\hline Usia & 35 & 29 & 37 \\
\hline Tempat tinggal & $\begin{array}{l}\text { Prumpung } \\
\text { Sawah }\end{array}$ & $\begin{array}{l}\text { Prumpung } \\
\text { Sawah }\end{array}$ & $\begin{array}{l}\text { Kebon } \\
\text { Singkong }\end{array}$ \\
\hline Agama & Islam & Islam & Islam \\
\hline $\begin{array}{l}\text { Pendidikan } \\
\text { terakhir }\end{array}$ & Tidak tamat SD & Tidak tamat SD & $\mathrm{SD}$ \\
\hline Status & Bercerai & Menikah & Menikah \\
\hline Jumlah anak & 3 & 2 & 5 \\
\hline $\begin{array}{l}\text { Usia anak } \\
(*=\text { anak yang } \\
\text { bekerja di jalanan })\end{array}$ & $\begin{array}{l}\text { A1. } 13 \text { tahun* } \\
\text { A2. } 9 \text { tahun* } \\
\text { A3. } 5 \text { tahun* }\end{array}$ & $\begin{array}{l}\text { B1. } 11 \text { tahun* } \\
\text { B2. } 4 \text { tahun* }\end{array}$ & $\begin{array}{l}\text { D1. } 18 \text { tahun } \\
\text { D2. } 16 \text { tahun* } \\
\text { D3. } 13 \text { tahun } \\
\text { D4. } 5 \text { tahun } \\
\text { D5. } 1 \text { tahun }\end{array}$ \\
\hline $\begin{array}{l}\text { Jenis kelamin } \\
\text { anak } \\
(\mathrm{P}=\text { perempuan } \\
\mathrm{L}=\text { laki-laki) }\end{array}$ & $\begin{array}{l}\text { A1. P } \\
\text { A2. P } \\
\text { A3. P }\end{array}$ & $\begin{array}{l}\text { B1. P } \\
\text { B2. P }\end{array}$ & $\begin{array}{l}\text { D1. P } \\
\text { D2. L } \\
\text { D3. L } \\
\text { D4. P } \\
\text { D5. P }\end{array}$ \\
\hline $\begin{array}{l}\text { Pendidikan anak } \\
\text { (yang bekerja di jalanan) }\end{array}$ & $\begin{array}{l}\text { A1. SMP } \\
\text { A2. SD } \\
\text { A3. Belum } \\
\text { bersekolah }\end{array}$ & $\begin{array}{l}\text { B1. SD } \\
\text { B2. Belum } \\
\text { bersekolah }\end{array}$ & $\begin{array}{l}\text { D2. Tidak } \\
\text { bersekolah }\end{array}$ \\
\hline
\end{tabular}




\section{Desain}

Penelitian ini menggunakan metode kualitatif dengan metode pengambilan data berupa wawancara. Pertanyaan-pertanyaan wawancara mengikuti konsep PMT. Terdapat empat tema besar yang dikaji dalam penelitian dengan konsep PMT, yaitu penilaian ancaman, penilaian coping, proteksi motivasi, dan perilaku proteksi (protection behavior). Penilaian ancaman dan coping adalah penilaian yang menghasilkan motivasi individu untuk menginisiasi, melanjutkan, atau justru menghalangi munculnya respons adaptif (motivasi proteksi). Penilaian ancaman meliputi penilaian terhadap bahaya dan seberapa besar kemungkinan terjadinya bahaya ketika bekerja di jalanan, serta keuntungan yang diperoleh karena anak bekerja di jalanan. Penilaian coping meninjau penilaian terhadap keyakinan bahwa respons mencegah anak bekerja di jalanan dapat menghindarkan anak dari bahaya, serta keyakinan dan hambatan untuk melakukan respons tersebut. Motivasi proteksi mengacu pada motivasi individu untuk menghindari ancaman, atau biasa didefinisikan sebagai intensi individu untuk menyetujui respons adaptif yang digunakan sebagai upaya menghindari bahaya. Sementara itu, perilaku proteksi adalah perilaku yang telah individu lakukan untuk menghindari ancaman (Rogers, 1983).

\section{Prosedur}

Persiapan awal yang dilakukan peneliti adalah mencari yayasan yang berfokus pada anak jalanan di Jakarta Timur. Peneliti menemukan sebuah yayasan yang dapat membantu peneliti menemukan partisipan, yaitu rumah singgah Swara. Program kerja yang dilakukan oleh yayasan ini beragam, mulai dari bidang pendidikan (kejar paket, beasiswa, dan rumah belajar), bidang kesehatan (bantuan makanan dan pengobatan gratis), serta pembinaan dan keterampilan usaha. Data terakhir dari rumah singgah Swara, terdapat kurang lebih 200 anak jalanan yang pernah atau masih mendapatkan pendampingan. Dalam implementasi program, rumah singgah Swara telah bekerja sama dengan Departemen Sosial RI, Dinas Sosial DKI Jakarta, Rumah Zakat Indonesia, dan lain sebagainya.

Peneliti meminta izin dan kesediaan dari rumah singgah Swara untuk membantu peneliti mencari subjek sesuai kriteria penelitian. Dalam melakukan penelitian, peneliti didampingi oleh koordinator anak jalanan di daerah Prumpung Sawah dan Kebon Singkong. Awalnya, peneliti menemukan lima subjek dan sempat mewawancarai semuanya. Namun, dua subjek batal diwawancarai lebih lanjut, karena satu subjek mengalami masalah pendengaran, sehingga peneliti kesulitan dalam menyampaikan pertanyaan dan 1 lagi tidak berkenan diwawancarai lebih jauh. 
Akhirnya, wawancara dilakukan kepada tiga subjek penelitian. Periode wawancara berlangsung dari bulan Maret sampai Juni 2016. Wawancara subjek A dan subjek B dilakukan masing-masing selama empat kali pertemuan. Wawancara subjek $\mathrm{C}$ dilakukan sebanyak tiga kali pertemuan. Durasi wawancara mulai dari 45-90 menit per pertemuan. Wawancara kepada setiap subjek mayoritas dilakukan di rumah subjek

\section{Teknik Analisis}

Peneliti menggunakan analisis tematik untuk menganalisis dan mengolah data hasil wawancara yang telah diubah ke dalam transkrip verbatim. Kerangka analisis yang dilakukan adalah dengan menggunakan konsep PMT. Beberapa langkah yang dilakukan peneliti adalah melakukan transkrip terhadap seluruh data wawancara yang terkumpul. Setelahnya dilakukan koding data, tema-tema besar yang menjadi fokus penelitian disesuaikan dengan komponen dalam konsep PMT. Tahap terakhir, peneliti melakukan analisis dan kesimpulan.

\section{ANALISIS DAN HASIL}

Peneliti membagi bagian analisis dan interpretasi data ke dalam empat tema besar. Tematema ini sesuai dengan konsep dari PMT. Keempat tema tersebut adalah penilaian ancaman, penilaian coping, motivasi proteksi, dan perilaku proteksi. Komponen penilaian ancaman menghasilkan motivasi individu untuk melakukan respons maladaptif. Komponen penilaian ancaman terdiri dari penilaian terhadap seberapa besar kemungkinan terkena ancaman tersebut (perceived vulnerability) dan kemungkinan munculnya keparahan ancaman (perceived severity). Ada satu aspek lain dalam penilaian ancaman, yaitu rewards yang justru meningkatkan kemungkinan individu melakukan respons maladaptif (Rogers, 1983).

Pada sisi lain, penilaian coping adalah proses untuk mengatasi dan mencegah terjadinya ancaman berbahaya. Proses terbentuknya penilaian coping adalah melalui terbentuknya keyakinan individu untuk melakukan tindakan mencegah terjadinya ancaman (respons efikasi) dan keyakinan apabila individu mampu melakukan tindakan tersebut (efikasi diri) (Floyd dkk., 2000). Ketika respons efikasi dan efikasi diri membantu terbentuknya kemungkinan respons adaptif, maka terdapat sejumlah response costs atau halangan untuk melakukan respons adaptif (Rogers, 1983).

Sementara itu, motivasi proteksi mengacu pada intensi individu untuk menghindari ancaman, atau dapat didefinisikan sebagai intensi individu untuk menyetujui respons adaptif yang digunakan untuk terhindar dari ancaman dan perilaku proteksi dapat didefinisikan sebagai perilaku 
atau respons adaptif yang telah dilakukan oleh individu untuk mencegah terjadinya ancaman (Rogers, 1983).

\section{Penilaian Ancaman}

Keuntungan yang diperoleh subjek A dan B ketika mengajak anaknya yang masih kecil bekerja di jalanan adalah keuntungan finansial yang umumnya digunakan untuk memenuhi kebutuhan sehari-hari keluarga. Kondisi ini terutama dirasakan oleh subjek A, apalagi sejak subjek A ditinggal oleh suaminya. Dengan mengamen bersama anaknya, Subjek A dapat mengumpulkan uang sampai 50 ribu rupiah dalam sehari.

"Itu anak doang. Bapaknya udah nga ada, engga ada bapak, engga punya suami. Yah namanya, suaminya punya istri lagi, tinggal bareng istri muda." (Subjek A, wawancara 31 Maret 2015).

"Saya, saya tuh nyari beras, nyari beras. Kalo abis pulang nyari beras, kerja jadi tukang cuci gosok. Abis kerja jadi tukang cuci gosok, ngamen..ngamen badut." (Subjek A, wawancara 31 Maret 2015).

Hal lainnya yang membuat subjek A membawa anaknya ikut bekerja di jalanan adalah karena anak-anaknya masih kecil, sehingga tidak mungkin ditinggal di rumah tanpa pengawasan. Subjek A tidak terlalu khawatir terhadap anaknya yang paling dewasa karena dianggap lebih mawas diri. Anak yang paling dewasa biasanya mulai bekerja di jalanan setelah pulang sekolah.

"Kalo masih ada orang tua masih enak. Kalo engga ada orang tua, mau titipin ama sapa juga takut. Takut ada orang jahat, ada yang ape gitu." (Subjek A, wawancara 3 April 2015).

Kondisi tidak berbeda jauh juga disampaikan oleh subjek B. Penghasilan suaminya kecil dan tidak jelas karena bekerja serabutan. Untuk memenuhi kebutuhan keluarga, subjek B terpaksa mengajak anaknya bekerja di jalanan. Bahkan, ia sudah mengajak anaknya ikut bekerja sejak anak paling tua masih berusia 2 tahun.

"Kadang dapet tiga puluh, dapet tiga lima, tergantung ramenya kak. Pulang jam 10. Udah pulang, beli susu kak, langsung beli susu atau kadang beli nasi. Entar sisanya berapa, sepuluh ribu buat pagi kak, buat sarapan." (Subjek B, wawancara 16 April 2015).

Sekarang anak subjek B yang paling tua sudah mengamen sendiri, tetapi tetap diawasi oleh neneknya. Subjek B memilih membawa anaknya yang kedua ikut bekerja di jalanan. Menurut 
subjek B, dengan mengajak anaknya yang masih kecil, penghasilan yang diperoleh dapat lebih besar.

Subjek A dan B juga memiliki penilaian tersendiri terhadap keuntungan yang diperoleh ketika anak mereka yang paling tua bekerja di jalanan. Subjek A dan B berpandangan bahwa penghasilan yang anak peroleh adalah hak anak dan digunakan oleh anak untuk memenuhi kebutuhannya sendiri. Paling tidak, keuntungan yang dirasakan oleh subjek A dan B adalah menjadi tidak terbebani untuk memberikan uang tambahan karena anaknya dapat mencari uang secara mandiri.

"Ngamen, mendingan ngamen lah kak (anak kedua subjek B) buat uang jajan-jajannya dia gitu kak.” (Subjek B, wawancara 16 April 2015).

"Yah alhamdulilah aja deh kak, dia bisa beli pakaian. Uangnya yah buat dia aja, saya mah engga pernah minta." (Subjek C, wawancara 13 Juni 2015).

Subjek C yang anaknya (usia 16 tahun) juga bekerja di jalanan justru merasa bersyukur, karena penghasilan dari ngamen dapat digunakan anak untuk membeli barang yang anak inginkan, seperti pakaian. Kondisi ini membantu meringankan beban ekonomi yang dirasakan. Hal ini dikarenakan anak subjek $\mathrm{C}$ hanya meminta sedikit uang jajan tambahan dan sisanya anak subjek $\mathrm{C}$ mencari sendiri dengan mengamen.

"Yah alhamdulilah aja deh kak, dia bisa beli pakaian. Uangnya yah buat dia aja, saya mah engga pernah minta." (Subjek C, wawancara 13 Juni 2015).

Terkait dengan bahaya yang mengancam anak ketika bekerja di jalanan, subjek A dan B pernah merasakan dikejar-kejar petugas keamanan dan ketertiban (Kamtib), ketika mengajak anaknya mengamen (anak subjek A dan B yang masih kecil). Meski demikian, hal ini tidak membuat subjek A dan B jera, karena merasa masih dapat menghindar dari Kamtib. Apabila pengawasan petugas sudah tidak ada, subjek A dan B akan mengamen lagi.

"Kemarin ada yang ketangkep, badutnya saya lemparin palanya. Lari, pas itunya ga ada. Terus diambil lagi palanya, pala badutnya. Ngumpet di rumah orang, untung dikasih rumah ya, ngumpet di sana." (Subjek A, wawancara 31 Maret 2015).

"Pernah sih waktu itu ama saya. Saya pura-pura nyebrang aja sih kak, krecekannya saya buang. Lewat kuburan Cina, saya lewat situ aja. Kalo ga ada Kamtib lagi, yah balik lagi."(Subjek B, wawancara 6 April 2015). 
Dampak dari risiko pembersihan adalah kurungan selama 6 bulan dan individu harus mengikuti pembinaan supaya tidak lagi berkegiatan di jalanan. Menurut subjek A, individu yang tertangkap bisa saja dibebaskan jika ada surat yang dibuat oleh pihak RT/RW setempat yang menjelaskan bahwa dirinya merupakan penghuni wilayah tersebut, serta bukan merupakan Penyandang Masalah Kesejahteraan Sosial (PMKS). Selain surat dari pihak RT/RW, individu yang tertangkap harus memberikan sejumlah uang jaminan yang bagi subjek A cukup besar jumlahnya.

"Soalnya kalo ada pembersihan lagi banyak banget, kita ga diurusin kalo masuk datadata di situ. Gara-gara kemaren tuh temen ketangkep..kalo ketangkep yayasan engga mau tanggung jawab. Kalo ketangkep pembersihan takut juga sih, dikasih pelatihan." (Subjek A, wawancara 21 April 2015).

Ada ancaman bahaya lain yang mungkin dihadapi anak subjek A dan B yang masih kecil ketika diajak bekerja di jalanan. Biasanya subjek dan anak dapat seharian mengamen di jalanan. Kondisi ini membuat anak rawan sakit dan kelelahan. Subjek A sebenarnya merasa kasihan karena anaknya sering sakit-sakitan.

"Tapi kasian, anak sakit, sama aja boong..mending dia di rumah, engga sakit. Tapi gimana kak, kehidupan gini susah. Ibarat kaya kita nyari duit cape, anak kan tubuhnya suka sakit-sakitan.” (Subjek A, wawancara 3 April 2015).

"Kalo ngamen, kita berangkat siang pulang malem. Udah capek, anak sakit." (Subjek A, wawancara 3 April 2015).

Kondisi lebih parah dialami oleh anak subjek B yang masih kecil (berusia 4 tahun). Anaknya sering mengalami sakit panas dan batuk-batuk setelah diajak seharian bekerja di jalanan, bahkan sempat mengalami kondisi kritis.

"Ya panas..berak-berak, batuk. Namanya kena angin malem gimana kak. Kalo udah gede sih kita udah ga gini. Kecil, masih kecil kasian. Udah kurang tidur, kita bawa ngamen." (Subjek B, wawancara 16 April 2015).

"Iya..anak saya yang tiga taon setengah ampir udah engga ada kak. Dirawat ampe dua kali, pertama kejang..kedua kalinya radang ama berak-berak.” (Subjek B, wawancara 16 April 2015).

Ancaman lainnya menurut subjek B ketika anak yang paling tua bekerja di jalanan adalah kemungkinan anak tertabrak kendaraan. Pengalaman ini pernah dialami oleh adik dari subjek B yang juga mengamen di jalanan. Sementara itu, subjek A belum pernah merasakannya secara langsung, tetapi sering mendengar berita tersebut. 
"Takutnya jatoh kak dilindes mobil. Kan adek saya pernah, di Rawamangun, kakinya patah. Untungnya saya bilang ibu saya, anak jalanan gitu kak, jadi bebas biaya. Tabrak lari bu, jadi ditanganin. Kan kakinya patah ampe lima bulan." (Subjek B, wawancara 31 Maret 2015).

Subjek B juga menilai anaknya yang paling tua rentan untuk melakukan kejahatan. Subjek B bercerita bahwa anaknya baru saja ketahuan mencuri baju di sebuah toko. Subjek B mengatakan bahwa anaknya dipaksa dan diancam oleh teman-temannya. Anak subjek B dan teman-temannya mencuri baju ketika pemilik toko sedang keluar. Anak subjek B disuruh untuk berjaga-jaga dan memberitahukan teman-temannya, jika pemilik toko sudah kembali. Anak subjek B dan temantemannya ketahuan, serta dikejar-kejar oleh pemilik toko. Anak subjek B dan teman-temannya lalu kabur melarikan diri.

Untungnya anak subjek B dan teman-temannya tidak tertangkap oleh pemilik toko, karena teman anak subjek B melemparkan baju yang dicuri ke jalanan. Subjek B khawatir jika anaknya tertangkap, anak subjek B akan digebuki oleh massa, dibawa oleh polisi, dan dipenjara. Kekhawatiran subjek B muncul karena subjek B sering melihat berita di televisi mengenai individu yang mencuri, kemudian ditangkap dan digebuki massa. Subjek B merasa dampak dari risiko pencurian yang dilakukan adalah ia dan anaknya akan dijelek-jelekan serta dicemooh oleh orang lain. Subjek B takut bahwa dirinya akan dicap sebagai orang tua yang tidak dapat mendidik dan mengajar anaknya untuk melakukan tindakan yang benar.

"Iya ama temennya. Ngambil engga seberapa kak, dijelek-jelekin ama orang-orang. Nanti dikira engga bisa didik anak..engga bisa ngajar anak." (Subjek B, wawancara 10 Mei, 2015).

Penilaian subjek $\mathrm{C}$ terkait ancaman yang dihadapi oleh anaknya ketika bekerja di jalanan tidak berbeda jauh dengan subjek A dan B. Permasalahan ditangkap Kamtib dan tertabrak kendaraan adalah hal yang dianggap mungkin saja dapat terjadi.

"Iya kan kalo di jalan takutnya kenapa-napa di jalan. Kan, kalo ketangkep Kamtib, namanya pembersihan banyak kak. Bukan cuma pengemis, pengamen juga dibawa. Iya kalo ketangkep Kamtib kan.dia bisa nangis-nangis kan kak." (Subjek C, wawancara 3 Juni 2015).

"Kan kalo jatoh dari mobil, kita engga tahu tuh. Mobil tau sendiri, kalo Metro kan ngebut..ngebut tuh.” (Subjek C, wawancara 3 Juni 2015).

Bahaya lain yang dinilai oleh subjek $\mathrm{C}$ adalah terkait dengan masalah kekerasan seksual dan penggunaan zat adiktif yang marak terjadi di sekitar lingkungan rumahnya. Subjek C pernah 
mendengar cerita tentang kasus kekerasan seksual yang dilakukan pada anak jalanan dan bahkan ada yang sampai dimutilasi.

"Kan waktu itu ada itu apa..sodomi, sodomi itu. Itu kan waktu zamannya sodomi itu, gedek..apa itu robot gedek. Itu pas taon berapa gitu, sebelom kebakaran kayanya. Banyak tuh katanya anak dimutilasi, itu katanya kolong pasar itu..anak jalanan, cowok lagi." (Subjek C, wawancara 3 Juni 2015).

Banyak pula di antara anak-anak yang suka meminum minuman oplosan serta menggunakan obat sejenis ganja atau tembakau.

"Ada ginseng..tu oplosan, ada juga ciu segala. Yah kalo udah berpengaruh tuh, yah susah. Ginseng tuh spiritus..buat mabok juga ada, ada juga tuh yang bau. Ginseng tuh diplastik, buat minum-minum gitu..ginseng.” (Subjek C, wawancara 13 Juni 2015).

"Banyak sih..banyak tuh yang gele. Kaya ganja, tembakau..yang di berita tuh daun dikeringin..ditumbuk, diinin pake kertas untuk rokok..dipelintingin, digiling ampe kecil..baru diseduh. Tapi baunya keciri, uh nyengatnya." (Subjek C, wawancara 13 Juni 2015).

\section{Penilaian Coping}

Subjek A dan B memiliki cara-cara tersendiri untuk mencegah ancaman, utamanya ketika melibatkan anak-anaknya yang masih kecil bekerja di jalanan. Subjek A sering bertanya kepada individu-individu yang biasanya mengetahui jadwal operasional Kamtib. Menurutnya, tidak semua Kamtib berperilaku kasar dan langsung menangkap para PMKS. Ada beberapa Kamtib yang justru memberikan informasi bahwa terdapat operasi penangkapan kepada para PMKS. Subjek penelitian mengatakan bahwa yang terpenting adalah harus bersikap baik dan sopan selama berkegiatan di jalanan.

"Ya diliat dulu kalo ada pembersihan ada dibilangin. Kalo kita orangnya enak, bisa diajak ngobrol ama sininya. Nanti dibilang jangan jalan, ada razia..jangan ngamen. Kalo kita orangnya ga enak..ya ga dikasih tau kak. Ibaratnya enaknya sama-sama ngobrol." "Ama Kamtibnya, yang baik ama kita..ada juga yang jahat." (Subjek A, wawancara 21 April 2015).

Subjek B merasa bahwa Kamtib biasanya melakukan pembersihan dan melakukan penangkapan PMKS di wilayah-wilayah tertentu saja, seperti di jalan raya. Hal ini membuat subjek A dan B memilih untuk mengamen di wilayah yang lebih aman, seperti perkampungan dan perumahan, ataupun mengamen di dekat lampu merah saja. Meskipun begitu, subjek A dan B masih memiliki ketakutan bahwa subjek dan anaknya akan ditangkap Kamtib, karena subjek A dan B 
harus tetap melewati jalan raya, jika ingin mengamen di perkampungan. Kondisi ini membuat risiko pembersihan tidak sepenuhnya dapat dihindari oleh subjek A dan B.

"Kalo Kamtib lewat deket jalan raya kan ditangkep juga. Kalo perumahan sih enak..Kampung Kapitan..terus Buaran. Tapi kan, Buaran lewat jalan raya juga..jadi ngeri. Apalagi sekarang banyak pembersihan..yah campur-campur la, ngamen..pengemis..yang bawa gerobak, ngeri.” (Subjek B, wawancara 6 April, 2015).

Sementara itu, untuk mencegah terjadinya ancaman kelelahan pada anak subjek A dan B yang masih kecil, subjek A dan B biasanya tidak setiap hari mengamen. Subjek A dan B memilih untuk beristirahat ketika anak merasa kelelahan.

"Saya lagi engga ngamen dulu kak, capek nih abis kemaren. Hari ini saya ke induk aja lebih enak di sana. Biasanya kalo capek, emang ga ngamen dulu, stop dulu." (Subjek A, wawancara 3 April 2015).

"Nih aja belom ngamen lagi, capek kak..males kak." (Subjek B, wawancara 6 April 2015).

Cara sedikit berbeda diterapkan oleh subjek A dan B supaya anaknya yang paling tua ketika bekerja di jalanan tidak menghadapi berbagai ancaman. Subjek A dan B melarang anaknya untuk mengamen jauh-jauh. Subjek A dan B telah mengetahui wilayah-wilayah yang umumnya rawan dan cukup berbahaya, sehingga memilih untuk menghindari wilayah tersebut.

\footnotetext{
"Kalo anak saya mah mulungnya deket-deket sini aja, wilayah sini aja..ga pernah jauhjauh. Engga saya bolehin juga. Di deket sini kan, dia kenal sama orang-orangnya, jadi gapapa." (Subjek A, wawancara 31 Maret, 2015).

"Ya gitu..anak saya ngamen engga jauh-jauh, kalo adek saya jauh gitu. Ada anak ngamen..kakak-kakakan gitu, adek-adek saya banyak kak..kayak kakak gitu..di lampu merah kalo malem. Yang bahaya tuh deket apa sih tuh namanya..yang banyak jablayjablay gitu.itu kan banyak di sono gitu..ngeri kak. Saya engga mau ngamen jauh-jauh gitu kak". (Subjek B, wawancara 6 April 2015).
}

Subjek B menjelaskan bahwa anaknya yang pertama biasa juga diawasi oleh neneknya ketika berkegiatan di jalanan. Subjek B tidak memperbolehkan anak mengamen sendirian tanpa adanya pengawasan dari si nenek. Subjek B juga terkadang mengawasi si anak, karena subjek B dan anaknya mengamen di wilayah yang sama. Ketika mengamen, anaknya biasa menggunakan kerudung dan baju muslim, supaya Kamtib tidak menyadari bahwa anak subjek B adalah pengamen jalanan. 
"Sering ama neneknya sih kak. Kalo sendiri neneknya juga waswas..kalo sendiri takut ada Kamtib, nanti dia lari kemana..ga bisa pulang. Ama neneknya sih kak, kalo ngamen pake baju Muslim..pake kerudungan. Bisa gampang sangkain ga ngamen kalo pake baju gitu. Sangkain kan dari mana, lagi nunggu mobil. Kalo ga pake gitu, sangkain ngamen..dikejer.” (Subjek B, wawancara 16 April 2015).

Sama seperti subjek A dan B, subjek C juga beranggapan anaknya cukup aman karena mengamen tidak jauh-jauh atau masih di sekitar wilayah dekat rumah. Subjek C berpendapat bahwa kecil kemungkinan anaknya dapat mengalami bahaya, seperti ikut-ikutan penyalahgunaan obatobatan dan minum-minuman keras, ataupun tertangkap Kamtib ketika bekerja di jalanan.

"Engga (tidak apa-apa mengamen) ..dia mah cuma gini doang, di sini Kodim disini. Engga lah, dia mah cuma teprak teprok doang. Tapi kan ati-ati, dia juga engga lama kan kalo ngamen. Kadang juga markir sih dia.” (Subjek C, wawancara 13 Juni 2015).

"Saya nasihatin, kan dia ngamen di Kodim, sini..balik lagi. Kalo ini juga paling di mall Citra doang." (Subjek C, wawancara 13 Juni 2015).

\section{Motivasi Proteksi}

Ketakutan dan rasa kasihan subjek A terkait ancaman terhadap dua anaknya yang masih kecil membuatnya berpikir ulang untuk mengajak mereka bekerja di jalanan. Subjek A merasa bahwa dirinya lebih baik bekerja untuk memenuhi kehidupan anak-anaknya, serta tidak membiarkan anaknya berada dalam situasi berisiko tinggi. Langkah terbaik yang subjek A pikirkan saat ini adalah sepenuhnya berhenti mengamen, serta mengandalkan penghasilan yang didapat ketika ke Pasar Induk Cipinang atau bekerja cuci gosok.

"Engga pernah..kasian. Kalo ga bawa anak, saya jabanin kak..kan kita bawa bocah. Kalo pulang malem..kasian, kalo sendiri gapapa. Tapi kalo sendiri juga kasian..anaknya ga ada yang jagain. Pengennya dagang di rumah..anak juga engga capek..kaya capek kasian. Ibarat kaya kita nyari duit cape..anak kan tubuhnya suka sakit-sakitan." (Subjek A, wawancara 21 April 2015).

"Udah pengennya sih engga ngamen lagi sih, pengen itu. Udah cari beras aja di Induk, udah ga usah ngamen lagi." (Subjek A, wawancara 21 April 2015).

Keinginan membuka usaha di rumah dan tidak membiarkan anaknya yang paling kecil ikut bekerja di jalanan, juga diutarakan oleh subjek B. Subjek B berkeinginan membuka usaha di rumah karena merasa kesulitan jika harus berdagang keliling dan mengawasi anaknya yang baru berusia tiga setengah tahun. Dengan berdagang, subjek B tidak perlu takut jika anaknya harus terkena angin malam dan sering sakit-sakitan. 
"Pengen kak punya usaha sendiri..di rumah gitu. Anak saya ga usah ngamen..saya biar sendiri dagang. Kasian kak..kalo ngamen malem-malem, kan angin kak..kan namanya angin." (Subjek B, wawancara 10 Mei 2015).

Akan tetapi, keinginan subjek A dan B supaya anak berhenti bekerja di jalanan, hanya difokuskan kepada anak-anak mereka yang masih kecil dan diajak bekerja. Penilaian berbeda diutarakan terkait dengan keinginan subjek A dan B terhadap anak yang paling tua ketika bekerja di jalanan. Menurut subjek B, apabila anaknya yang paling tua tidak mengamen, maka subjek B tidak akan punya uang untuk jajan sekolah.

"Biasa Bu, ngamen. Makanya jangan ngamen, kata guru anak subjek B, yah gimana bu kalo ga ngamen, ga punya duit, ga bisa buat jajan sekolah. Emang guru tau kalo duitnya..ga punya duit." (Subjek B, wawancara 10 Mei 2015).

"Mending ngamen aja lah dia (anak tertua subjek B), biar dapet uang bisa buat jajannya dia." (Subjek B, wawancara 6 September 2015).

Sementara itu, subjek A lebih membebaskan anaknya yang paling tua memilih untuk bekerja di jalanan atau tidak. Apabila anaknya sudah tidak mau lagi mengamen atau memulung, subjek A tidak masalah. Apabila anaknya masih mau mengamen, subjek A juga tidak melarang selama tidak mengamen jauh-jauh. "Yah terserah anaknya deh kak, kalo mau..ya gapapa, kalo capek, ya ga ngamen. Terserah dia kak, udah besar. Cuma yang penting, jangan jauh-jauh..saya selalu nasihatin." (Subjek A, wawancara 21 April 2015).Kondisi serupa juga dirasakan oleh subjek C. Subjek C memang menilai bahwa seharusnya anak tidak boleh bekerja di jalanan. Akan tetapi, baginya si anak sudah dewasa, sehingga hal tersebut bukan merupakan sebuah masalah.

"Iya (harusnya mencegah anak berkegiatan), tapi sekarang mah udah gede itu, yaudah dia di jalanan lah." (Subjek C, wawancara 13 Juni 2015).

Menurutnya, asalkan si anak dapat berhati-hati di jalanan, ancaman tersebut bukan merupakan masalah. Apalagi anak subjek C sudah cukup dewasa (usia 16 tahun).

"Takut juga sih, paling ati-ati..udah gede, dia bisa ini. Dulu waktu SD..masih waswas, soalnya dia masih kecil..tau sendiri metromini, dia bisa langsung jalan." (Subjek C, wawancara 3 Juni 2015).

Berbeda kondisinya waktu si anak mengamen saat masih SD. Waktu itu, seringkali subjek C berusaha melarang anaknya bekerja di jalanan. Akan tetapi, si anak seringkali kembali mengamen, sehingga akhirnya subjek $\mathrm{C}$ pun membiarkannya. Yang terpenting bagi subjek $\mathrm{C}$ adalah si anak dapat menjaga dirinya sendiri. 
"Takut saya, sayanya takut..bapaknya juga takut. Namanya anak masih kecil, kan namanya anak, kita engga tau kak. Kadang-kadang ngamennya ngumpet. Pas jam sekolah, saya nyamperin ke sekolah..wah engga ada nih..pasti ngamen. Saya susulin..saya tungguin di Gapura kak, saya bawa pulang..waktunya sekolah, sekolah. Tapi entar ngamen lagi, pas pulang. ." (Subjek C, wawancara 13 Juni, 2015).

\section{Perilaku Proteksi}

Subjek A memutuskan untuk mencoba mencari pekerjaan, namun sejauh ini ia masih belum berhasil dan masih mengalami penolakan. Subjek A ingin hidupnya dapat lebih maju daripada sekedar pergi ke Pasar Induk, karena sejauh ini uang yang diperoleh sangat terbatas untuk memenuhi kebutuhan sehari-hari keluarga. Kondisi ini membuatnya tetap bertahan untuk bekerja di Pasar Induk dan berjualan minuman. Subjek A mengatakan bahwa dirinya mulai jarang mengamen bersama dengan anaknya di jalanan belakangan ini.

"Kan kalo ngamen ato ke Induk lagi, engga ada kemajuan kak. Pengennya ada pengalaman, ada kerja, lumayan tuh uangnya tiga juta kalo kerja. Pengennya gitu, engga usah ke Induk lagi. Rumah bisa kebayar, makan bisa kebayar. Kalo ke Induk kan cuma bisa makannya doang, pas gitu. Engga ada lebih-lebihnya, kalo kerja kan mending." (Subjek A, wawancara 6 September 2015).

"Sekarang sih usahain udah engga ajak anak lagi deh (yang kecil) ngamen. Kasian kak, coba aja kerja di Induk sekarang. Kalo ngamen yah kalo kepepet aja, engga tiap ari”. (Subjek A, wawancara 6 September 2015).

Subjek B juga mulai mengurangi durasi untuk mengajak anaknya yang paling kecil untuk bekerja di jalanan. Hanya saja, subjek B masih bekerja di jalanan ketika keluarganya sedang tidak memiliki uang. Meskipun demikian, subjek B sudah mulai mencoba berjualan bubur dengan meminjam uang sebagai modal. Selama berdagang, subjek B mengatakan bahwa uang yang diperoleh sangat pas-pasan dan cenderung kurang. Jika kehabisan modal, maka subjek B harus mengamen lagi bersama anaknya.

"Baru kemarin kak, kan sekarang kita jualan bubur kacang ijo, ni makanya ngamen lagi pere (stop) dulu kak.” (Subjek B, wawancara 6 September 2015).

Perbedaan perilaku ditunjukkan oleh subjek A dan B terhadap anak mereka yang paling tua. Saat ini, subjek A dan B masih mengizinkan dan membebaskan anak-anaknya untuk bekerja di jalanan. Untungnya, anak subjek A juga mulai malu untuk terus-terusan mengamen di jalanan, 
sehingga aktivitias tersebut mulai jarang anak subjek A lakukan. Keinginan anak untuk berhenti bekerja di jalanan direstui dan disetujui oleh subjek A.

"Udah engga mau ngamen ah mak. Ya udah saya bilang di rumah aja deh, bagus biar engga kenapa-kenapa, saya aja yang ngamen. Paling sekarang kalo dia mau cari uang jajan, cuma mulung-mulung aja deket sini sih, engga jauh-jauh.” (Subjek A, wawancara 31 Maret 2015).

Kondisi berbeda dialami oleh subjek B. Anaknya yang pertama masih memiliki niat untuk bekerja di jalanan, sehingga subjek B pun mengizinkan supaya anak bisa mendapatkan uang jajan.

"Ngamen, mengingan ngamen lah kak buat uang jajan-jajannya dia gitu kak." (Subjek B, wawancara 6 September, 2015).

"Sering masih, tapi minggu mungkin engga yah..pere. Masih ama neneknya ini dia. Kasian kak kalo tiap ari, mungkin minggu dia istirahat. Tapi kalo lagi mau yah jalan. Yaudah terserah dia aja maunya gimana." (Subjek B, wawancara 6 September 2015).

Subjek C juga mengizinkan anaknya untuk bekerja di jalanan. Ia merasa tidak khawatir dengan masalah yang mungkin dialami oleh si anak, karena menganggap anaknya sudah besar dan dapat menjaga dirinya sendiri.

"Iya (harusnya mencegah anak berkegiatan), tapi sekarang mah udah gede itu, yaudah dia di jalanan lah.” (Subjek C, wawancara 13 Juni 2015).

Subjek menganggap keinginan untuk bekerja di jalanan merupakan keinginan dari si anak sendiri.

"Yah izinin aja kak. Abis anaknya maunya gitu. Sekarang masih sering ngamen di deket sini kak, itu deket-deket anak-anak sekolah kak.” (Subjek C, wawancara 13 Juni 2015).

\section{Rangkuman Hasil Analisis Ketiga Subjek Penelitian}

Berdasarkan temuan di lapangan, anak-anak bekerja di jalanan dikarenakan dua hal. Pertama, anak-anak ini sejak kecil diajak oleh ibunya untuk bekerja di jalanan. Hal ini dialami oleh anak dari subjek A dan B. Ketika si anak mulai beranjak besar, mereka mulai bekerja di jalanan seorang diri atau bersama dengan temannya. Penyebab kedua, ada seorang anak, yaitu anak subjek C, mulai bekerja di jalanan sejak usia sekolah karena diajak oleh teman-temannya. Keuntungan yang diperoleh utamanya adalah keuntungan finansial, kondisi ini yang membuat semua ibu mengizinkan anak untuk bekerja di jalanan. Keuntungan finansial yang diperoleh ibu ketika mengajak anaknya yang kecil bekerja di jalanan, membantu ibu untuk memenuhi kebutuhan ekonomi keluarga. Apalagi, uang yang diperoleh akan lebih besar apabila para ibu mengajak 
anaknya yang masih kecil. Sementara, keuntungan finansial yang diperoleh anaknya yang sudah lebih dewasa umumnya digunakan oleh si anak sendiri untuk jajan dan anak tidak lagi tergantung dengan orang tua untuk membeli barang yang diinginkan.

Para ibu mengizinkan anaknya bekerja di jalanan karena memperoleh beberapa keuntungan. Namun di sisi lain, ada beberapa ancaman yang dikhawatirkan para ibu ketika anaknya bekerja di jalanan. Seluruh subjek menilai bahwa bahaya yang dihadapi adalah tertangkap Kamtib dan bisa mengalami kecelakaan di jalanan. Sementara itu, ancaman-ancaman lainnya hanya dinilai oleh sebagian subjek penelitian. Ancaman tersebut di antaranya adalah melakukan kejahatan, mengalami kekerasan, dan melakukan penyalahgunaan zat adiktif. Ada ancaman lain yang khusus dirasakan oleh ibu yang mengajak anaknya yang masih kecil bekerja di jalanan, yaitu si anak dapat mengalami sakit dan kelelahan. Ancaman-ancaman yang dipersepsikan tergantung dari pengalaman kerabat mereka ataupun kabar dari lingkungan sekitar.

Para ibu sebenarnya merasa bahwa cara terbaik untuk mencegah terjadinya ancaman pada anak adalah tidak lagi membiarkan anak untuk bekerja di jalanan. Sayangnya, kebanyakan di antaranya tidak yakin untuk mencegah anak bekerja. Kondisi ini berkaitan dengan adanya biaya yang harus ditanggung apabila anak berhenti bekerja di jalanan. Biaya yang dimaksud adalah hilangnya keuntungan yang diperoleh ibu dan si anak.

Ibu lebih memilih untuk mencari cara lain yang sekiranya dianggap dapat meminimalisir kemungkinan anak menghadapi ancaman. Ibu yang anaknya sudah lebih dewasa menganggap bahwa anak cukup diingatkan dan diawasi, selama ini para ibu juga menilai anak jarang mengalami ancaman-ancaman tersebut dan merasa bahwa kondisinya masih relatif aman. Kondisi berbeda dialami oleh ibu yang mengajak anaknya masih kecil bekerja di jalanan. Para ibu secara nyata mengalami sendiri ancaman-ancaman tersebut dan juga melihat bagaimana kondisi anak yang rentan terhadap sakit dan kelelahan, sehingga walaupun sudah melakukan beberapa cara, para ibu tetap menganggap anak rentan untuk menghadapi ancaman.

Penilaian para ibu terhadap ancaman dan cara mencegah terjadinya ancaman, membentuk motivasi para ibu untuk mencegah anak bekerja di jalanan. Para ibu yang anaknya lebih dewasa tampak tidak memiliki masalah ketika anaknya bekerja di jalanan. Para ibu lebih memilih membebaskan anaknya untuk bekerja ataupun tidak, bahkan subjek $\mathrm{C}$ cenderung mendorong anak bekerja di jalanan. Sementara, ibu yang anaknya lebih kecil cenderung mulai berpikir untuk berhenti mengajak anak bekerja di jalanan karena ancaman yang berbahaya dan rentan dialami oleh anak. Pada akhirnya, subjek A dan B yang biasa mengajak anaknya yang masih kecil, mulai jarang untuk bekerja di jalanan. Subjek A dan B memilih untuk mencoba mencari pekerjaan ataupun 
berdagang dibandingkan bekerja di jalanan. Hanya saja, terkadang aktivitas subjek A dan B kurang menghasilkan, sehingga subjek A dan B terpaksa kembali mengajak anaknya bekerja di jalanan.

\section{DISKUSI}

Partisipan dalam penelitian ini seluruhnya adalah anak-anak yang dapat dikategorikan sebagai anak yang bekerja di jalanan, yaitu anak-anak yang menghabiskan waktu di jalanan. Anakanak tersebut mempunyai kegiatan ekonomi sebagai pekerja anak, akan tetapi rutin pulang ke rumah. Anak-anak ini masih mempunyai hubungan yang kuat dengan orang tuanya dan sebagian penghasilannya diberikan kepada orang tuanya. Pada kategori ini, fungsi anak jalanan adalah untuk membantu keluarganya karena beban atau tekanan kemiskinan yang harus ditanggung dan tidak dapat diselesaikan oleh orang tua anak (UNICEF, 2001).

Hasil penelitian menunjukkan bahwa keuntungan finansial menjadi daya tarik bagi ibu untuk mengizinkan anak bekerja di jalanan. Hal ini sesuai dengan apa yang disampaikan Rogers (1983) bahwa rewards baik secara intrinsik atau ekstrinsik akan meningkatkan kemungkinan individu untuk melakukan respons maladaptif. Masalah finansial terjadi karena keterbatasan pendidikan yang membuat para ibu mengalami kesulitan untuk mencari pekerjaan. Para suami juga memiliki pekerjaan yang tidak menentu. Para suami dapat bekerja dan memeroleh penghasilan yang cukup untuk memenuhi kebutuhan keluarganya jika memiliki pekerjaan tertentu. Penghasilan ini baru diperoleh setelah seluruh pekerjaan yang dilakukan selesai. Jika tidak ada pekerjaan yang menjanjikan, para suami umumnya hanya menjadi supir bus dan tukang sampah. Temuan ini sejalan dengan hasil penelitian UNICEF (2007) dan De Moura (2002) tentang faktor-faktor penyebab anak bekerja di jalanan.

Mayoritas dari para ibu tampak tidak terlalu risau dengan keberadaan anak di jalanan, utamanya anak mereka yang sudah cukup dewasa. Para ibu beranggapan bahwa anak-anaknya sudah dewasa, sehingga mampu menjaga dirinya sendiri. Hal ini membuat para ibu merasa tidak perlu mencegah anak bekerja di jalanan. Para ibu merasa dengan mengingatkan anak untuk berhatihati dan mengawasi apa yang dilakukan oleh anak sudah cukup untuk menghindarkan anak dari ancaman. Meskipun ada kesadaran bahwa anak seharusnya tidak bekerja di jalanan. Namun, para ibu tidak yakin untuk melakukannya karena ada biaya yang harus dikeluarkan, yaitu kehilangan keuntungan yang diperoleh dari kegiatan si anak. Hal ini sesuai dengan penjelasan Rogers (1983), keyakinan individu tentang efektivitas respons dan keyakinan bahwa individu mampu melakukan respons tertentu akan menghasilkan respons adaptif. Namun, ada pula costs yang harus dibayar dan 
menjadi halangan untuk melakukan respons adaptif. Akhirnya, para ibu memilih untuk membiarkan anak bekerja di jalanan dan hanya melakukan strategi alternatif untuk meminimalisasi terjadinya ancaman pada anak. Temuan ini serupa dengan pendapat Shalahuddin (2010), bahwa orang tua seakan "mengamini" anak untuk beraktivitas jalanan. Bagi orang tua, hal ini seolah bukan merupakan sesuatu yang memalukan atau aib. Sebagian orang tua bahkan menjadi pelaku eksploitasi ekonomi terhadap anak-anak mereka sendiri.

Persepsi para ibu tampak berbeda apabila anak yang dimaksud adalah anak-anaknya yang masih kecil. Para ibu sadar kerentanan dan keparahan terhadap ancaman lebih besar. Apalagi, para ibu juga merasakan sendiri beratnya bekerja di jalanan. Rogers (1983) menjelaskan bahwa penilaian terhadap ancaman dan coping melibatkan sumber informasi yang diperoleh selama hidup individu. Kondisi ini dialami oleh ibu yang melihat anak-anaknya sering sakit dan mengalami kelelahan. Adanya ancaman ini membuat para ibumerasa bahwa cara terbaik yang seharusnya dilakukan adalah mencegah anak bekerja di jalanan.

Meskipun demikian, masalah yang dialami apabila para ibu berhenti mengajak anak bekerja adalahkehilangan keuntungan finansial. Biaya ini menjadi masalah karena tanpa bekerja di jalanan, keluarga tidak memiliki uang yang cukup untuk kebutuhan sehari-hari. Untungnya, para ibu masih berupaya untuk mencari alternatif strategi lain untuk memeroleh uang tanpa harus membiarkan anaknya bekerja di jalanan, yaitu dengan bekerja atau berdagang. Hanya saja, apabila kondisi finansial sedang parah atau para ibu tidak memiliki modal, para ibu terpaksa kembali mengajak anak-anaknya bekerja di jalanan.

Dalam penelitian ini terlihat konsep rewards dan costs yang dijelaskan oleh Rogers sebenarnya memiliki makna yang serupa. Hanya saja, rewards diartikan sebagai keuntungan yang diperoleh ketika melakukan respons maladaptif, sementara costs adalah kehilangan rewards akibat melakukan respons adaptif. Selain itu, ibu yang merasa bahwa anaknya tidak terlalu menghadapi ancaman berbahaya, lebih memilih untuk tidak mempermasalahkan keberadaan anak di jalanan. Namun di sisi lain, ibu yang merasa bahwa anaknya rentan mengalami ancaman berbahaya akan lebih sadar mengenai keharusannya untuk melakukan respons adaptif berupa mengajak anak bekerja di jalanan. Ibu yang mempunyai penilaian terhadap ancaman yang lebih berbahaya umumnya adalah para ibuyang anak-anaknya masih kecil. Pada akhirnya, para ibu memilih untuk mencoba berhenti mengajak anaknya yang masih kecil bekerja di jalanan dan mencari pekerjaan lain. Namun, para ibu tetap membiarkan anaknya yang sudah lebih dewasa dan dianggap mandiri untuk bekerja di jalanan. 


\section{SIMPULAN DAN SARAN}

\section{Simpulan}

Penelitian ini berupaya menemukan penilaian ibu terhadap upaya mencegah anaknya bekerja di jalanan. Ibu yang memiliki anak yang sudah lebih dewasa (memasuki fase usia remaja) umumnya menilai bahwa ancaman yang dihadapi oleh anak-anaknya ketika bekerja di jalanan tidak parah dan berbahaya. Para ibu lebih memilih untuk mengingatkan anak-anaknya untuk berhati-hati. Para ibu memutuskan untuk membiarkan anaknya bekerja di jalanan karena adanya keuntungan finansial yang dapat dihasilkan oleh si anak. Biasanya, keuntungan ini digunakan oleh anak untuk jajan atau membeli barang yang diinginkan, sehingga tidak merepotkan orang tua.

Perbedaan penilaian terjadi pada ibu yang mengikutsertakan atau mengajak anak-anaknya yang masih kecil bekerja di jalanan. Para ibu merasa bahwa anak rentan menghadapi ancaman berbahaya, terutama jatuh sakit dan kelelahan. Para ibu juga tidak menyangkal bahwa kehadiran anak bersama para ibu membuat pendapatan dari jalanan semakin meningkat. Hanya saja, adanya ancaman-ancaman ini membuat para ibu merasa takut dan akhirnya memilih untuk berupaya berhenti mengajak anaknya bekerja di jalanan. Para ibu berusaha menggantikan keuntungan dari bekerja di jalanan dengan melakukan pekerjaan lain, seperti berdagang atau berwirausaha. Sayangnya, ketika para ibu benar-benar kesulitan ekonomi, maka para ibu terpaksa harus kembali mengajak anaknya bekerja di jalanan.

\section{Saran Teoretis}

Hasil penelitian kualitatif dengan PMT umumnya juga berguna untuk menemukan informasi yang menonjol terkait dengan motivasi individu untuk melakukan respons adaptif. Data penelitian kualitatif dapat digunakan sebagai saran dan rekomendasi untuk mengembangkan dan menghasilkan isi butir pool yang nantinya akan dipilih untuk diseleksi dalam kuesioner PMT (Norman dkk., 2005). Penelitian PMT dengan menggunakan metode kualitatif pernah dilakukan oleh Searle, Vedhara, Norman, Frost, dan Harrad (2000). Mereka melakukan penelitian untuk menyelidiki perspektif orang tua terhadap penggunaan eye patching pada anak dengan penyakit amblyopia. Selanjutnya, penelitian dengan topik serupa dilakukan menggunakan metode kuantitatif untuk memprediksi ketaatan orang tua untuk merekomendasikan penggunaan eye patching kepada anak dengan penyakit amblyopia (Norman, Searle, Harrad, \& Vedhara, 2003). 


\section{Saran Praktis}

Hasil penelitian dapat digunakan sebagai bagian dari intervensi dalam rangka mengubah penilaian ibu dan membuat para ibu termotivasi untuk mencegah anaknya bekerja di jalanan. Berdasarkan hasil analisis, ada beberapa cara yang dapat dilakukan dalam melakukan intervensi. Pertama, masalah mendasar yang membuat para ibu membiarkan anak bekerja di jalanan adalah masalah ekonomi atau finansial. Untuk itu, intervensi yang dapat dilakukan adalah membuat si ibu atau ayah dapat berdaya, sehingga ekonomi keluarga membaik, termasuk membantu para ibu dan ayah untuk bekerja ataupun memulai usaha. Hal ini menjadi penting, khususnya bagi para ibu yang mengajak anaknya bekerja di jalanan sejak kecil.

Cara intervensi kedua adalah pemberian edukasi kepada ibu mengenai pentingnya anak untuk memeroleh pendidikan dan terkait pemberian pola asuh yang tepat. Sebagian anak bekerja di jalanan karena umumnya diajak oleh teman-teman mereka. Kondisi ini bahkan mengakibatkan ada anak yang memilih untuk putus sekolah. Untuk itu, para orang tua harus dapat mengawasi dan menjaga anaknya supaya memiliki pergaulan yang benar.

Cara intervensi ketiga, para ibu juga sebaiknya diberikan informasi terkait ancaman riil yang dapat dihadapi oleh anak ketika bekerja di jalanan. Hal ini menjadi penting untuk meningkatkan kesadaran para ibu mengenai ancaman yang dapat dihadapi anak, khususnya bagi para ibu yang sebenarnya tidak pernah berada di 'dunia jalanan'.

Pendekatan langsung kepada anak jalanan tidak boleh diabaikan, utamanya apabila anak jalanan sudah berusia remaja, karena keputusan bekerja di jalanan adalah keputusan mereka. Pendekatan represif seperti penangkapan tidak begitu efektif karena banyak anak jalanan yang tidak jera dan masih tetap bekerja di jalanan.

\section{UCAPAN TERIMA KASIH}

Peneliti mengucapkan terima kasih kepada Endang Mintarja, Hardiansyah, Pipit, dan Sri Wahyuni yang telah membantu dalam mencari dan mempertemukan peneliti dengan partisipan. Ucapan terima kasih juga kami ucapkan kepada Dhevy Setya Wibawa dan Idhamsyah Eka Putra yang telah meluangkan waktunya untuk memberikan saran dan masukan bagi tulisan ini. 


\section{REFERENSI}

Badan Pusat Statistik Provinsi DKI Jakarta. (2013). Jakarta dalam Angka 2013. Ditemu kembali dari https://jakarta.bps.go.id/publication/2013/08/16/3881d1fcb10d7acb8e88ec52/jakartadalam-angka-2013.html

De Moura, S. (2002). The social construction of street children: Configuration and implications. British Journal of Social Work, 32(3), 353-367. doi: 10.1093/bjsw/32.3.353

Dinas Sosial Daerah Istimewa Yogyakarta. (2018). Jenis-Jenis PMKS. Ditemu kembali dari dinsos.jogjaprov.go.id/jenis-jenis-pmks/

Floyd, D. L., Dunn, S. P., \& Rogers, R. W. (2000). A meta-analysis of research on protection motivation theory. Journal of Applied Social Psychology, 30(2), 407-429. doi: 10.1111/j.1559-1816.2000.tb02323.x

Gunarsa, S. D., \& Gunarsa, S. Y. (2008). Psikologis praktis: Anak, remaja, dan keluarga (8th ed). Jakarta: Gunung Mulia.

Handy, F., \& Soedjatmiko, S. (2004). Masalah kesehatan dan tumbuh kembang pekerja anak jalanan. Jurnal Sari Pediatri, 5(4). doi: 10.14238/sp5.4.2004.138-44

Kementerian Sosial Republik Indonesia. (2017). Anak Jalanan. Ditemu kembali dari kemsos.go.id/content/anak-jalanan

Komisi Perlindungan Anak Indonesia. (2014). Undang-undang Republik Indonesia nomor 35 tahun 2014 tentang perubahan atas undang-undang nomor 23 tahun 2002. Ditemu kembali dari kpai.go.id/hukum/undang-undang-republik-indonesia-nomor-35-tahun-2014-tentangperubahan-atas-undang-undang-nomor-23-tahun-2002-tentang-perlindungan-anak/

Marks, D. F. (2002). The health psychology reader. London: Sage.

Milne, S. (2000). Prediction and intervention in health-related behavior: A meta-analytic review of protection motivation theory. Journal of Applied Social Psychology, 30(1), 106-141. doi: 10.1111/j.1559-1816.2000.tb02308.x

Norman, P., Searle, A., Harrad, R., \& Vedhara, K. (2003). Predicting adherence to eye patching in children with amblyopia: An application of protection motivation theory. British Journal of Health Psychology, 8, 67-82.

Norman, P., Boer, H., \& Seydel E. R. (2005). Protection motivation theory. Dalam M. Conner \& P. Norman (Eds.), Predicting health behaviour: Research and practice with social cognition models (hlm. 81-126). Maidenhead: Open University Press. 
Nuryetty, M. T., Susilo, D., Chamami, A., Santoso, B., Setiawan, A., Nugroho, S.W., \& Astuti. (2012). Profil PMKS: Penyandang masalah kesejahteraan sosial Indonesia 2011. Jakarta: Pusat Data dan Informasi Kesejahteraan Sosial.

Persada, K. B. (2012). Kekerasan personal terhadap anak jalanan sebagai individu di ruang publik (Skripsi tidak dipublikasikan). Universitas Indonesia, Jakarta.

Rogers, R. W. (1983). Cognitive and physiological processes in fear appeals and attitude change: A revised theory of protection motivation. Dalam J. Cacioppo \& R. Petty (Eds.), Social Psychophysiology (hlm. 153-176). New York, NY: Guilford Press.

Rogers, R. W., \& Dunn, S. P. (1997). Protection motivation theory. Dalam Gochman, D. S. (Ed.), Handbook of health behavior research I: Personal and social determinants (hlm. 153-132). New York, NY: Plenum.

Searle, A., Vedhara, K., Norman, P., Frost, A., \& Harrad, R. (2000). Compliance with eye patching in children and its psychosocial effects: A qualitative application of protection motivation theory. Psychology, Health \& Medicine, 5(1), 43-54.

Sedayu, A. (2010). Kriminolog: Anak jalanan rentan jadi korban pembunuhan. Tempo. Ditemu kembali dari 100tempo.co/read/news/2010/01/09/064218196/Kriminolog-Anak-JalananRentan-Jadi-Korban-Pembunuhan

Shalahuddin, O. (2010). 230.000 anak jalanan di Indonesia. Yayasan Setara. Ditemu kembali dari yayasansetara.org/23-000-anak-jalanan-di-indonesia/

Sutton, S. (2001). Health behavior: Psychosocial theories. Dalam N. J. Smelser \& P. B. Baltes (Eds.). International Encyclopedia of the Social and Behavioral Sciences (hlm. 6499-6506). Oxford: Elsevier.

Suyanto, B. (2010). Masalah sosial anak. (Edisi revisi). Jakarta: Prenadamedia.

UNICEF. (1989). Konvensi hak-hak anak. Ditemu kembali dari unicef.org/magic/media/documents/CRC_bahasa_indonesia_version.pdf

UNICEF. (2001). Orphans and other vulnerable children and adolescents in Zimbabwe. Ditemu kembali dari unicef.org/evaldatabase/files/ZIM_01-805.pdf

UNICEF. (2007). Children in the street: The Palestinian case. Ditemu kembali dari abudis.net/ChildrenintheStreetEnglish.pdf 